\title{
Profile of Cybernetic Thinking of Students in Mathematical Problem Solving Based on Serialist and Holist Thinking Style
}

\author{
Aning Wida Yanti' ${ }^{1}$ Kusaeri ${ }^{2}$, Mia Kustianingsih ${ }^{3}$ \\ 1,2,3 Mathematics Education, UIN Sunan Ampel Surabaya, Indonesia \\ 1aning.widayanti@uinsby.ac.id, kusaeri@uinsby.ac.id, 1 mia.kustianingsih@gmail.com
}

\section{Article History:}

Received : 10-06-2020

Revised 1 : 13-07-2020

Revised 2 : 15-09-2020

Accepted : 16-09-2020

Online : :03-10-2020

\section{Keyword:}

Cybernetic thinking; Mathematical problem; Serialist thinking styles; Holist thinking styles.



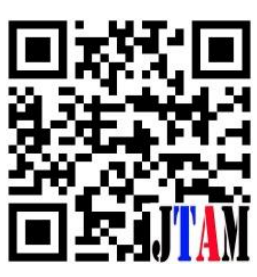

ABSTRACT

This research aim to describe the profile of cybernetic thinking of students in solving algebra problems. This research is a descriptive study with a qualitative approach using questionnaires, written tests, and interview guidelines. Intake of subjects who have Serialist and Holist thinking styles have done using purposive sampling. The results showed students who have the Serialist thinking style at the time of the Sensory Register's attention and good perception so that information stored in Short Term Memory. Retrieval done well even when rehearsal has difficulty because of forgetting certain concepts, but information has been stored well in Long Term Memory. The encoding done well. While students who have Holist style of thinking lack attention and perceptions are not structured so that information is not stored correctly in Short Term Memory. So that retrieval can not be done correctly. Therefore during rehearsal, they have difficulty in applying the settlement method because the information is not stored correctly in Long Term Memory.
\end{abstract}

\section{doi) 3 crossref}

https://doi.org/10.31764/itam.v4i2.2403

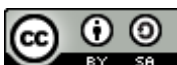

This is an open access article under the CC-BY-SA license

\section{A. INTRODUCTION}

The results of Trends in International Mathematics and Science Study (TIMSS) in 2015, Indonesian students in solving mathematical problems are still far from the international. Indonesian students are still unable to solve problems in the low category (Annajmi, 2018) (Lailiyah et al., 2018). Indonesian students are still unable to solve problems in the low category. One of the mathematical problems is algebra material that is one of the subjects considered difficult for students (Kieran, 2004; Saul, 2008).

The inability of students to solve algebraic problems is the biggest weakness of students in learning algebra material, namely writing down the notions of tribes, variables, and constants (Ma'Rufi et al., 2017). The same thing was stated by (Jupri \& Drijvers, 2016) that students experience difficulties because algebra is required to do reasoning or abstract thinking related to ethnicity, variables, and constanta (Kusaeri, 2012). Therefore, students are a failure in solving algebra problems caused by students failing to memorize, process, and implement 
(call back) information related to tribes, variables, and constanta. The result that Indonesian students were weak in processing information that impacted the failure of students in solving algebra problems than it was not excessive if teachers were required to be able to choose the right learning theory to be applied to students (Kieran, 2004).

Students in solving algebra problems are required to do the thought process. The thought process is a process that starts with receiving data first, then processes and stores it in memory, then retrieved from memory when needed for subsequent processing or in the stage to understand information(Ulya et al., 2014). While some cognitive psychologists reveal that thinking as an activity carried out by the brain system to process information mentally or cognitively (Kusaeri, 2012; Lestari et al., 2018).

One theory that discusses the flow of thought processes is the Cybernetics theory. According to Siswono, cybernetics is a process that begins by receiving data, processing, and storing it in memory, which is then taken back from memory when needed to solve problems (Ulya et al., 2014). Cybernetic learning theory kind of the learning theories related to information processing explains that learning is information processing, however even more important is the information system in determining student success in solving problems (Bednar \& Welch, 2014). Cybernetics theory has delivered by prominent scientists, including Landa and Pask \& Scott. Landa (1976) is one of the psychologists who are cybernetics. According to Landa, there are two kinds of processes in thinking in Cybernetics, namely algorithmic thought processes and heuristic thought processes.

Based on Gurbin's research, she said the processing information is a relatively easy way to understand the complex functions in the human brain needed to think and act (Amamah et al., 2016). Therefore, in the implementation of information processing, there is a relationship between students and thought processes in solving a problem. At the same time, the Cybernetics theory was able to improve the ability to solve problems in every learning at the level of education (Arvyaty et al., 2015).

Some cybernetics figures describe the information processing component into three. First, Sensory Receptors are cells where information first received from outside. Second, Short Term Memory is a part of human memory, assumed to be able to take data from notice individuals. Third, Long Term Memory is a type of memory that stores a lot of information for a long time in a relatively permanent way (Khairani, 2017). The Sensory Register is first a cell received from outside. Sensory registers receive information or stimuli from the environment like light, sound, odor, heat, color, etc. continuously through receptors. Receptors are called sensory organs for seeing, hearing, smelling, touching, and feeling. Information received is stored in a sensory register for approximately 2 seconds (Suyono, 2011). Information processing is closely related to cognitive learning theory that explains the process, storage, and recall of knowledge from the brain. Component of the cognitive process of information processing consists of attention, perception, retrieval, rehearsal, and encoding (Xiong \& Proctor, 2018). Different styles of thinking can cause differences in understanding of information processing. These differences can cause each individual to have a problemssolving way in each individual. When students do problem-solving activities, students may use different ways of thinking in solving problems (Supriadi et al., 2015).

In solving problems, students are required to absorb, process, and understand information based on information processing carried out (Charters, 2003). Problem-solving is a process or individual effort to respond or overcome obstacles when an answer or answer method is not yet clear (Siswono, 2016). Whereas Posamentier and Krulik (2015) define the problem as a challenging question, not routinely encountered, and the solution cannot be known immediately. One must find the best way out by using all his abilities to solve the problem. The ability to solve this problem includes the ability to understand, design mathematical models, solve models, and interpret the solutions obtained (Irianti et al., 2016). Problem- 
solving can assume as a process where students associate between a combination of rules that they have learned first and then used to solve new problems. But solving the problem is not only to apply for a known but also to try finding new knowledge (Abdullah, 2018). While solving mathematical problems is a process carried out by students to solve mathematical problems using the knowledge and understanding they have (Indah et al., 2016).

Stages in the activities of students' thought processes in solving mathematical problems divided into four stages, including (1) Receiving information, (2) Processing information, (3) Saving information, (4) Calling information back (Liljedahl et al., 2016; Rahman \& Ahmar, 2016). Pask and Scott (1973) distinguish two types of thinking. First, serialist is a type of thinking that tends to use a local approach and concentrate on various topics separately before building connect each subject. Second, Holist is a kind of global thinking, examining the interconnectedness of several materials from the beginning of the learning process, and concentrating on building an overall picture of an issue at the beginning of the process (Clewley et al., 2011). One of the cybernetic theory figures is Pask and Scott (1973). According Clewley et al., (2011) there are two styles of thinking of students in the Cybernetics theory, namely the Serialist style and the Holist style. Serialist style students usually have something in common like algorithmic thinking. The Holist style tends to learn something from the generalization stage to a specific (Pane \& Darwis Dasopang, 2017).

The cybernetic theory is present as an alternative solution to the failure of students to solve problems caused a failure in processing information, and Cybernetic theory can improve the ability to solve problems. Therefore, the purpose of this study is to describe the cybernetic thinking profile of students in solving mathematical problems according to the Serialist and Holist thinking styles.

\section{B. METHODS}

This research is a descriptive study with a qualitative approach. The research method in the form of a description of a situation or event, written or oral words, sentences, images, and behavior that observed and directed at the individual's scientific background as a whole (Nazir, 2009). This research has conducted at SMPN 2 Taman Sidoarjo. The data collection process has carried out on Grade VIII as many as 30 students who had get algebra material. The subjects chosen using a purposive sampling technique attention to students' communication skills and accepting the results of input and information from the teacher (Noor, 2016). The students chosen were students who were able to express their ideas or opinions well and finish answers from the subject. How to get the subject of research? Researchers provide a learning type questionnaire that is useful for classifying students who have Serialist and Holist thinking styles by making 20 statements. Based on these items two students have selected who had Serialist thinking styles and two students who had Holist thinking styles. In addition to using a questionnaire, researchers conducted interviews with subjects related to students' thinking styles both in writing and orally so as not to influence the results of this study. The students selected the following Table 1.

Table 1. Research subject

\begin{tabular}{cccc}
\hline No. & Inisial & Kode & Thinking style (follow Pask \& Scott) \\
\hline 1. & RR & $\mathrm{S}_{1}$ & Serialist \\
\hline 2. & IRS & $\mathrm{S}_{2}$ & Serialist \\
\hline 3. & MDD & $\mathrm{S}_{3}$ & Holist \\
\hline 4. & MF & $\mathrm{S}_{4}$ & Holist \\
\hline
\end{tabular}


The techniques used in collecting data are: (1) Thinking Questionnaire Technique, (2) Cybernetic Thinking Writing Test Techniques, (3) Interview Techniques. While the supporting instruments are: Questionnaire Thinking Style, Writing Test Thinking Cybernetic, and Interview Guidelines. Questionnaire technique is many written questions that use to obtain information from the respondent, in the sense of a report about his personality or things he wants to know (Ingleby, 2012)(Charters, 2003).

In this study, the validity test has carried out using triangulation techniques, which are different data collection techniques to get the same data source. The analysis techniques are Analysis of the results of the questionnaire style of thinking, written test of Cybernetic thinking, and interview. Activities in data analysis are reduction, display, and conclusion/verification. The research procedures carried out included four stages, including (1) The preparation phase, (2) The implementation phase, (3) The data analysis stage, and (4) The report preparation stage (Sugiyono, 2018).

\section{RESULT AND DISCUSSION}

The data presented were obtained from research conducted on two subjects who have Serialist thinking styles and two students who have Holist thinking styles. They were given by a written test to identify their cybernetics thinking. They must fill out the questionnaire that had provided and do a written test, after which interviews conducted on each research subject. Following is the description of the Cybernetics thinking profile of students who have Serialist thinking styles in solving mathematical problems.

Table 2. Profile of Cybernetic Thinking of Students in Mathematical Problem Solving with Serialist Thinking Style

\begin{tabular}{|c|c|c|}
\hline $\begin{array}{c}\text { Components } \\
\text { of Cybernetic } \\
\text { Theory } \\
\end{array}$ & $\mathbf{S}_{1}$ & $\mathbf{S}_{2}$ \\
\hline & $\begin{array}{l}\text { S1 has received information in the form } \\
\text { of mathematical problems in the SPLDV } \\
\text { material by understanding and re- } \\
\text { reading the question, then determining } \\
\text { some components to link in solving the } \\
\text { problem. Shows that the subject stores } \\
\text { information in the Sensory Register } \\
\text { (sense of sight). } \\
\text { The Attention Process carried out by S1 } \\
\text { is by sorting out the information } \\
\text { contained in the questions. S1 can } \\
\text { explain the problem that is known and } \\
\text { is sufficient to understand the } \\
\text { information provided in the questions. } \\
\text { The Perception process carried out by } \\
\text { S1 is to determine what material is } \\
\text { related to the problem given and how } \\
\text { to solve the problem or what strategies } \\
\text { will be used to obtain the correct } \\
\text { problem-solving. }\end{array}$ & $\begin{array}{l}\text { S2 has received information in the form } \\
\text { of mathematical problems in the SPLDV } \\
\text { material by understanding and read the } \\
\text { question more than once. Based on this } \\
\text { analysis shows that S2 stores } \\
\text { information in the Sensory Register. } \\
\text { The Attention Process conducted by S2 } \\
\text { is by sorting out the information } \\
\text { contained in the questions. S2 reveals } \\
\text { what is known, asked from the } \\
\text { explanation of the picture that has given. } \\
\text { S2 has sorted out information by } \\
\text { mentioning or writing down what is } \\
\text { known and asked about the problem. } \\
\text { The Perception process carried out by } \\
\text { S2 in resolving a given problem is by } \\
\text { first changing it into a linear equation. }\end{array}$ \\
\hline Conclu & \multicolumn{2}{|c|}{$\begin{array}{l}\text { The cybernetic thinking profile of students with the Serialist thinking style begins } \\
\text { with the entry of information into the Sensory Register by observing images and } \\
\text { reading the questions given. The process of attention to the question done to sort } \\
\text { out information and reveal what is known and asked. The Perception process } \\
\text { determines what material is related and how to solve the problem or what }\end{array}$} \\
\hline
\end{tabular}




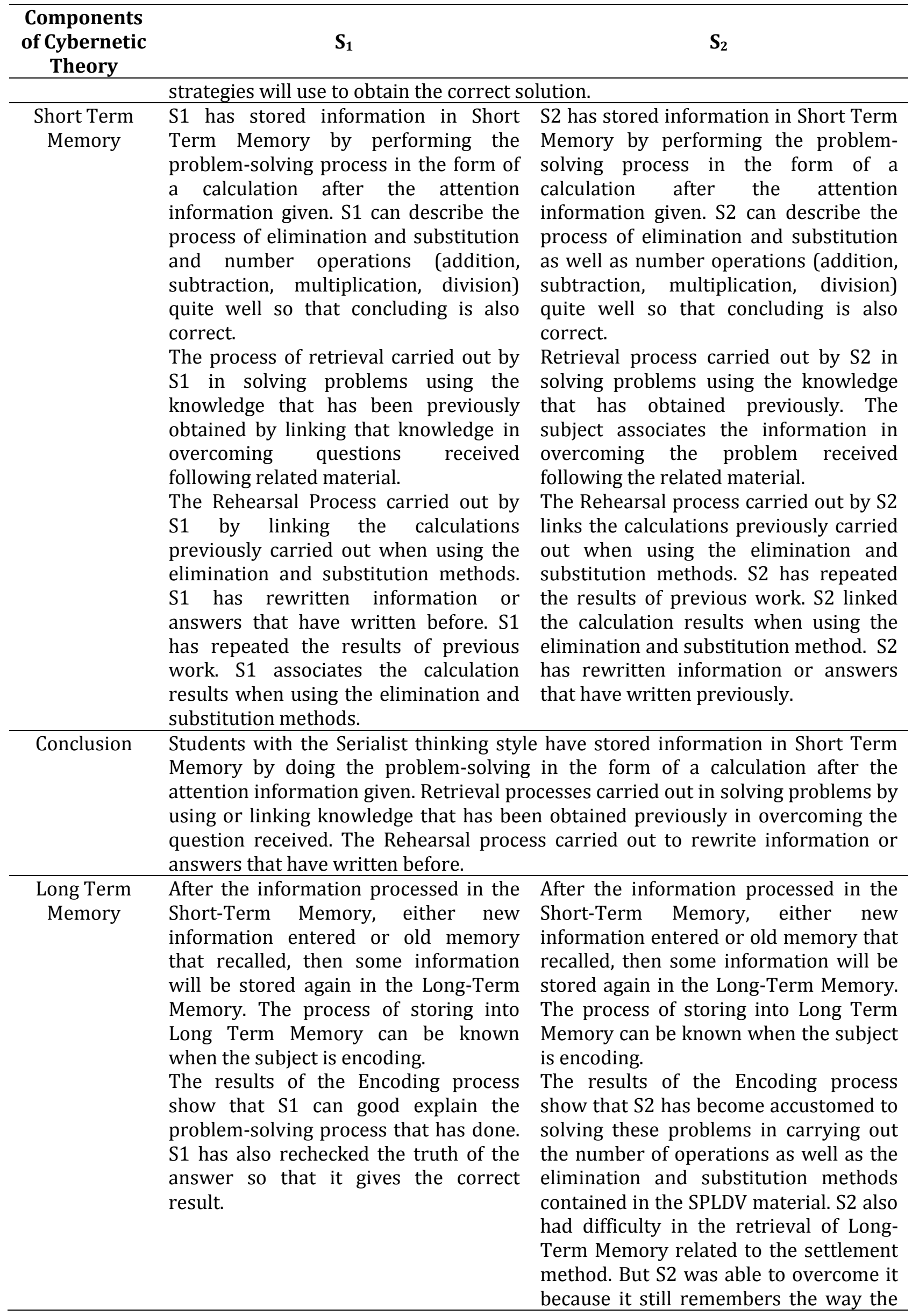




\begin{tabular}{cl}
$\begin{array}{c}\text { Components } \\
\text { of Cybernetic } \\
\text { Theory }\end{array}$ & \multicolumn{1}{c}{$\mathbf{S}_{\mathbf{1}}$} \\
\hline & $\begin{array}{c}\text { teacher worked on the explanation he } \\
\text { had received. S2 can explain in a } \\
\text { structured process the problem solving } \\
\text { that has done. The subject has also } \\
\text { rechecked the truth of the answer so } \\
\text { that it gives the correct result. }\end{array}$ \\
\hline Conclusion & $\begin{array}{l}\text { Students with the Serialist thinking style save goods concepts in Long Term } \\
\text { Memory to be applied to Short Term Memory when needed to solve problems and }\end{array}$ \\
& $\begin{array}{l}\text { can explain the answers that have done. The encoding process that done already } \\
\text { feels accustomed to solving problems and still can remember the way of working } \\
\text { from the teacher's explanation that he had received. }\end{array}$ \\
\hline $\begin{array}{l}\text { Cybernetic thinking profiles of students who have Serialist thinking styles in } \\
\text { solving mathematical problems based on components of Cybernetetic theory begin } \\
\text { with the entry of information into the Sensory Register by correcting pictures and } \\
\text { reading the questions. Attention and Perception processes can carry out well so } \\
\text { that information stored in Short-Term Memory. The Retrieval Process can do well } \\
\text { after that, the rehearsal process increases the difficulty of students replacing } \\
\text { forgetfulness for concepts. It needed Short-Term Memory to solve the } \\
\text { mathematical problems that have stored in students' Long-Term Memory. The } \\
\text { coding process is correct so that it answers correctly. }\end{array}$
\end{tabular}

Following is the description of the Cybernetic thinking profile of students who have Holist thinking styles in solving mathematical problems.

Table 3. Profile of Cybernetic Thinking of Students in Mathematical Problem Solving with Holist Thinking Style

\begin{tabular}{|c|c|c|}
\hline $\begin{array}{c}\text { Components } \\
\text { of Cybernetic } \\
\text { Theory } \\
\end{array}$ & $\mathbf{S}_{3}$ & $\mathbf{S}_{4}$ \\
\hline $\begin{array}{l}\text { Sensory } \\
\text { Register }\end{array}$ & $\begin{array}{l}\text { S3 stores information in the first } \\
\text { information store, the Sensory } \\
\text { Register (the sense of sight and } \\
\text { hearing). } \\
\text { The Attention Process carried out by } \\
\text { S3 is merely giving value to each of } \\
\text { the building blocks contained in } \\
\text { each tower, such as rectangular } \\
\text { rectangles, hexagons, and stars. } \\
\text { The Perception Process carried out } \\
\text { by S3 in determining what material } \\
\text { is related to the problem given and } \\
\text { how to solve the problem or what } \\
\text { strategies will use to obtain the } \\
\text { correct problem solving, S3 does not } \\
\text { use a structured way like that used } \\
\text { by most of his friends. S3 only looks } \\
\text { at the picture in the question, then } \\
\text { makes calculations with the } \\
\text { reasoning that is useful for knowing } \\
\text { the answer to the problem given. }\end{array}$ & $\begin{array}{l}\text { S4 stores information in the first repository } \\
\text { of information the Sensory Register (the } \\
\text { sense of sight and sense of hearing) with } \\
\text { reading and understanding images } \\
\text { repeatedly that have been read by } \\
\text { researchers. } \\
\text { The Attention Process carried out by S4 is } \\
\text { by sorting the information in the problem. } \\
\text { S4 shows only giving values to buildings } \\
\text { that have dotted lines on tower III and } \\
\text { writing down the unity value of the flat } \\
\text { structures that make up the section. } \\
\text { The Perception process carried out by S4 in } \\
\text { determining what material is related to a } \\
\text { given problem and how the subject will } \\
\text { solve the problem or what strategies will } \\
\text { use to obtain the correct solution to the } \\
\text { problem. S4 does not use structured } \\
\text { methods as used by most of his friends. S4 } \\
\text { only looks at the picture in the question, } \\
\text { then makes calculations with the reasoning } \\
\text { that is useful for knowing the answer to the }\end{array}$ \\
\hline
\end{tabular}




\begin{tabular}{|c|c|c|}
\hline $\begin{array}{l}\text { Components } \\
\text { of Cybernetic } \\
\text { Theory }\end{array}$ & $\mathbf{S}_{3}$ & $\mathbf{S}_{4}$ \\
\hline & & problem given. \\
\hline Conclusion & $\begin{array}{l}\text { Cybernetic thinking profile of students } \\
\text { entry of information into the Sensory R } \\
\text { hearing) by observing images and read } \\
\text { to the researchers' explanations. The at } \\
\text { Perception Process is not structured. }\end{array}$ & $\begin{array}{l}\text { with Holist thinking style begins with the } \\
\text { egister (the sense of sight and sense of } \\
\text { ing the questions given and when listening } \\
\text { tention process is to do only modestly. The }\end{array}$ \\
\hline $\begin{array}{c}\text { Short Term } \\
\text { Memory }\end{array}$ & $\begin{array}{l}\text { S3 has stored information in Short } \\
\text { Term Memory in the form of } \\
\text { knowledge or concepts needed in } \\
\text { solving problems related to how to } \\
\text { determine the number of rectangles } \\
\text { in tower III. but it is not good. S3 } \\
\text { does not use the formula in its } \\
\text { solution but only uses reason and } \\
\text { uses calculation operations that } \\
\text { have obtained. } \\
\text { The Retrieval process carried out by } \\
\text { S3 experienced forgetting to } \\
\text { remember the same problem and } \\
\text { had been explained by the } \\
\text { mathematics teacher before. So S3 } \\
\text { uses his way to solve the questions } \\
\text { obtained. It shows that the subject } \\
\text { only associates knowledge about the } \\
\text { calculation operations without } \\
\text { linking the methods that have been } \\
\text { explained by the teacher before } \\
\text { solving problems. } \\
\text { The Rehearsal process carried out } \\
\text { by S3 in the process of finding the } \\
\text { number of rectangles in tower III, by } \\
\text { linking the calculations previously } \\
\text { carried out at the initial stage, } \\
\text { namely the calculation operation } \\
\text { that reduces the height of tower I to } \\
\text { tower II. Then S3 performs the } \\
\text { calculation operation of tower III } \\
\text { height reduced by the total number } \\
\text { of known building values on tower } \\
\text { III. So, from the results of the } \\
\text { analysis, S3 found the number of } \\
\text { rectangular buildings in tower III in } \\
\text { a phased manner from the initial } \\
\text { calculation. Based on this analysis } \\
\text { shows that S3 has rewritten } \\
\text { information or answers that have } \\
\text { written previously. }\end{array}$ & $\begin{array}{l}\text { S4 has stored information in Short Term } \\
\text { Memory. S4 can describe the process of } \\
\text { solving mathematical problems as well as } \\
\text { performing number operations (addition, } \\
\text { subtraction, multiplication, division) quite } \\
\text { well, even though it uses a method that is } \\
\text { not quite right. The conclusions drawn are } \\
\text { appropriate. } \\
\text { The Retrieval process carried out by S4 uses } \\
\text { reasoning in solving problems. By } \\
\text { measuring the unit value of each known } \\
\text { rectangle, then linking when calculating the } \\
\text { number that will be attached to tower III. } \\
\text { The method used is to divide the height of } \\
\text { the building contained in the dotted line by } \\
\text { the known square unit value. } \\
\text { The Rehearsal process carried out by S4 in } \\
\text { the process of looking for the number of } \\
\text { rectangles in tower III, by linking the } \\
\text { calculations previously done at an early } \\
\text { stage is to measure with the help of a unit } \\
\text { value ruler from the rectangular building on } \\
\text { the tower I and tower II. So from the results } \\
\text { of the analysis, S4 found the number of } \\
\text { rectangular buildings in tower III by } \\
\text { stepwise from the initial calculation, then } \\
\text { proceeded to divide the height of the } \\
\text { building that has the dotted line by the unit } \\
\text { value of the previous rectangle. After doing } \\
\text { calculations, S4 found the number of } \\
\text { rectangular in tower III is } 6 \text {. it is means S4 } \\
\text { has rewritten information or answers that } \\
\text { have written previously }\end{array}$ \\
\hline Conclusion & \multicolumn{2}{|c|}{$\begin{array}{l}\text { Students with Holist thinking style are not good at storing information into Short } \\
\text { Term Memory were in the process of solving using other methods that are not } \\
\text { following the material and reasoning in solving the problems given and doing a } \\
\text { calculation in solving the problem. The Retrieval process carried out had forgotten }\end{array}$} \\
\hline
\end{tabular}




\begin{tabular}{|c|c|}
\hline $\begin{array}{c}\text { Components } \\
\text { of Cybernetic } \\
\text { Theory }\end{array}$ & $\mathbf{S}_{4}$ \\
\hline & $\begin{array}{l}\text { to remember the same problem and had been explained by the mathematics } \\
\text { teacher before and only used his reasoning. The Rehearsal process carried out had } \\
\text { difficulty in implementing the settlement method because it was caused by } \\
\text { forgetting. }\end{array}$ \\
\hline $\begin{array}{l}\text { Long Term } \\
\text { Memory }\end{array}$ & $\begin{array}{l}\text { After the information processed in the } \begin{array}{l}\text { After the information processed in the } \\
\text { Short-Term Memory, either new }\end{array} \text { Short-Term Memory, either new } \\
\text { information entered or old memory } \\
\text { information entered or old memory that } \\
\text { that recalled, then some information recalled, then some information will be } \\
\text { will be stored again in the Long-Term stored again in the Long-Term Memory. } \\
\text { Memory. The process of storing into The process of storing into Long Term } \\
\text { Long Term Memory can be known } \\
\text { when the subject is encoding. } \\
\text { The results of the coding process } \\
\text { is encoding. } \\
\text { carried out by S3 showed that S3 was carried out by S4 already feel familiar } \\
\text { familiar with the structure of the with the structure of the problem, both } \\
\text { question, both what believed and asked, what is known and asked about the } \\
\text { but used other methods to solve it question, but used other methods to } \\
\text { without using formulas or methods solve it without using formulas or } \\
\text { following the material provided. S3 is methods following the material provided. } \\
\text { less able to explain the question S4 is less able to explain clearly the } \\
\text { problem-solving process that has done. problem-solving process that has done } \\
\text { because it uses a less precise way. }\end{array}$ \\
\hline Con & $\begin{array}{l}\text { Students with Holist thinking style are not good at storing concepts in Long Term } \\
\text { Memory to be applied to Short Term Memory when needed to solve problems and } \\
\text { are less able to explain the answers that have done using the wrong method. in the } \\
\text { encoding process they feel familiar with the structure of the question, but have } \\
\text { difficulty in using the formula or the appropriate way. Therefore, they used another } \\
\text { way. }\end{array}$ \\
\hline Summary & $\begin{array}{l}\text { Cybernetic thinking profile of students who have a Holist thinking style in solving } \\
\text { mathematical problems based on components of Cybernetetic theory begins with } \\
\text { the entry of information into the Sensory Register (senses of sight and sense of } \\
\text { hearing) by images and reading the given problems and listening to the } \\
\text { researchers' explanations. The attention process that done only modestly and the } \\
\text { Perception process that done does not use a structured way so that the information } \\
\text { not stored in the Short-Term Memory. The retrieval process had forgotten to } \\
\text { remember the same problem and explained by the math teacher before. They have } \\
\text { used his reasoning. The Rehearsal process that carried out had difficulty in applying } \\
\text { the method of settlement because it was caused by forgetting. The information was } \\
\text { not well stored in Long Term Memory. The encoding process carried out using } \\
\text { other methods to complete without using a formula or method that is following the } \\
\text { material provided due to difficulties in remembering it. }\end{array}$ \\
\hline
\end{tabular}

Cybernetic thinking profile of students who have the Serialist thinking style in solving algebra problems begin from the presence of information or stimulus in the form enter the Sensory Register through the sense of sight by reading questions. It is following the research of Amamah et al. (2016) that information entered into the Sensory Register based read activities. Then students have attention and perception. Students who have the Serialist style of thinking make attention by sorting out information that is on the problem so that the formation is focused. Prinz in (Rehalat, 2016) has the same opinion attention is some information meaning to new information, and connected to existing knowledge. Perception 
will be realized by students when doing the problem-solving process in Short Term Memory by doing the retrieval. Thus, students also have experienced forgetting to do a Retrieval of a particular concept because forgetfulness is at risk for waste. Students who have the Serialist thinking style in understanding concepts more associate the knowledge they have previously obtained, and the problem-solving material provided, students have experienced forgetting of particular concepts because students use memorization methods in learning (Clewley et al., 2011). Understanding concepts of students often use procedural abilities and are at risk of experiencing waste due to difficulties in carrying out retrieval on a particular.

Pask (1976) said students who have Serialist thinking styles tend to use local approaches and concentrate on various topics separately first before building interest between material. From these results, it shows that the components of information storage and cognitive processes of students who have Serialist thinking styles are functioning well even though there has been a portion of memory lost in solving mathematical problems.

Cybernetic thinking profile of students who have a Holist style of thinking in solving mathematical problems starts from the presence of information or stimulus in the form of questions given by researchers who enter the Sensory Register through the senses of sight and hearing. Students who have a Holist style of thinking do different thought processes. The thinking process starts with information in the form of questions. Students who have the Holist thinking style receive information by reading the questions and listening to the explanation given by the researcher. Then the information in the form of the problem is entered into the Sensory Register. Based on research by (Ngilawajan, 2013), information entered into the sensory list through reading or listening activities. Reading activities carried out indicate that these students have used their sense of sight to understand while listening activities to record information received. The ability of students to solve mathematical problems influence by several things, including the ability of students to identify everything known in the question given as capital to determine strategies and initial steps.

The same opinion was conveyed by Gagné (1975) that an individual's ability to identify a given problem affects the experience and knowledge of the individual. Students pay attention and give perception. Students complete the process and experience errors in using the appropriate concepts due to forgetfulness and have other ways to solve problems that stored in Long-Term Memory. As a result, the response in the form of answers given by students is not quite right but also has good value due to chance because there are other ways to solve the problem. That is because the concepts needed Short Term Memory are not well stored in Long Term Memory. Students often experience errors due to forgetfulness and the risk of overgeneralizing.

The Holist style of thinking in problem-solving slightly relates prior knowledge due to frequent failures in recalling. They Solve many problems using reasoning and not to use the concept according to the material given along a piece of information stored in Long Term Memory. Students use descriptive skills because some of them only a few are stored in Long Term Memory. Refers to Pask (1976) that students who have a Holist thinking style tend to use a global approach and examine the interests of various topics since the beginning of the learning process and concentrate on building a comprehensive picture of a problem at the beginning of the process.

\section{CONCLUSION AND SUGGESTIONS}

Based on the results of data analysis and discussion, it can be concluded that: (1) Cybernetetic thinking of students who have Serialist thinking style in solving algebra problems begin from the information that goes into the Sensory Register and performs Attention and Perception well. So, that information stored well in Short Term Memory and do Retrieval well even though Rehearsal has difficulty because students experience forgetting of 
certain concepts so that information is stored well in Long Term Memory and Encoding properly so that responses in the form of answers given are correct; (2) Cybernetetic thinking of students who have Holist thinking style in solving algebra problems begin from the information that enters the Sensory Register, attention and poorly perception and does not use a structured way. So, that is less well stored into Short Term Memory and Retrieval experience forgetting to remember the same problems and have been explained before and only using their reasoning and Rehearsal which have difficulty in applying the method of resolution. Because it is caused to forget so that the information is not well stored in Long Term Memory and encoding which is carried out using other methods to solve without a formula or way that is in accordance with the material given due to difficulties in remembering it. The researcher suggestions to teachers, such as must teach methods that make students not only memorize but also pay more attention to students' diverse thought processes even though they do not follow them. Besides that, the teacher also pays attention to the students' initial abilities that are stored in long term memory.

\section{REFERENCES}

Abdullah. (2018). Pendekatan Dan Model Pembelajaran Yang Mengaktifkan Siswa. EDURELIGIA: Jurnal Pendidikan Agama Islam, 1(2), 45-62. https://doi.org/10.33650/edureligia.v1i2.45

Amamah, S., Sa'dijah, C., \& Sudirman. (2016). Proses Berpikir Siswa SMP Bergaya Kognitif Field Dependen dalam Menyelesaikan Masalah Berdasarkan Teori Pemrosesan Informasi. Jurnal Pendidikan: Teori, Penelitian, Dan Pengembangan, 1(2), 237-245.

Annajmi, A. (2018). Kontribusi Disposisi Matematis terhadap Prestasi Belajar Matematika Siswa Kelas VIII SMPN 3 Tambusai. EDUMATICA / Jurnal Pendidikan Matematika, 8(01), 1-8. https://doi.org/10.22437/edumatica.v8i01.4730

Arvyaty, Jazuli, L. O. A., Rosdiana, Hasnawati, Y. E. Y. K., \& Tiya, K. (2015). Development of Learning Devices of Cybernetic Cooperative in Discussing the Simplex Method in Mathematics Education Students. International Journal of Education and Research, 3(2), 589-598.

Bednar, P., \& Welch, C. E. (2014). Applying cybernetic thinking to becoming a learning organization. Kybernetes, 43(9/10), 1319-1329.

Charters, E. (2003). The Use of Think-aloud Methods in Qualitative Research An Introduction to Thinkaloud Methods. Brock Education Journal, 12(2), 68-82. https://doi.org/10.26522/brocked.v12i2.38

Clewley, N., Chen, S. Y., \& Liu, X. (2011). Mining learning preferences in web-based instruction: Holists vs. Serialists. Educational Technology and Society, 14(4), 266-277.

Gagné, R. M. (1975). Essentials of learning for instruction. New York : Dryden/Holt, Rinehart \& Winston. Indah, S. T., Subanji, \& Dwiyana. (2016). Proses Berpikir Siswa Tunanetra dalam Menyelesaikan Masalah Matematika Ditinjau dari Teori Pemrosesan Informasi. Jurnal Pendidikan - Teori, Penelitian, Dan Pengembangan, 1, 1265-1278. https://doi.org/10.17977/jp.v1i7.6528

Ingleby, E. (2012). Research methods in education. Professional Development in Education, 38(3), 507509. https://doi.org/10.1080/19415257.2011.643130

Irianti, N. P., Subanji, S., \& Chandra, T. D. (2016). Proses Berpikir Siswa Quitter dalam Menyelesaikan Masalah SPLDV Berdasarkan Langkah-langkah Polya. JMPM: Jurnal Matematika Dan Pendidikan Matematika, 1(2), 133-142. https://doi.org/10.26594/jmpm.v1i2.582

Jupri, A., \& Drijvers, P. (2016). Student Difficulties in Mathematizing Word Problems in Algebra. EURASIA Journal of Mathematics, Science and Technology Education, 12(9), 2481-2502. https://doi.org/10.12973/eurasia.2016.1299a

Khairani, M. (2017). Psikologi Belajar. Yogyakarta : Aswaja Pressindo.

Kieran, C. (2004). Algebraic thinking in the early grades: What is it. The Mathematics Educator, 8(1), 139-151.

Kusaeri, K. (2012). Menggunakan Model DINA Dalam Pengembangan Tes Diagnostik Untuk Mendeteksi Salah Konsepsi. Jurnal Penelitian Dan Evaluasi Pendidikan, 16(1), 281-306. https://doi.org/10.21831/pep.v16i1.1118

Lailiyah, S., Nusantara, T., Sa'dijah, C., Irawan, E. B., Kusaeri, \& Asyhar, A. H. (2018). Structuring 
students' analogical reasoning in solving algebra problem. IOP Conference Series: Materials Science and Engineering, 296(1), 012029. https://doi.org/10.1088/1757-899X/296/1/012029

Landa, L. N. (1976). Instructional regulation and control: Cybernetics, algorithmization, and heuristics in education. Englewood Cliffs, NJ:Educational Technology Publications.

Lestari, D., Testiana, G., \& Agustiani, R. (2018). Kemampuan Berpikir Kreatif Siswa dengan Pendekatan Pendidikan Matematika Realistik Indonesia (PMRI). Jurnal Pendidikan Matematika RAFA, 4(1), 79-92. https://doi.org/10.19109/jpmrafa.v4i1.3766

Liljedahl, P., Santos-Trigo, M., Malaspina, U., \& Bruder, R. (2016). Problem Solving in Mathematics Education (pp. 1-39). https://doi.org/10.1007/978-3-319-40730-2_1

Ma'Rufi, Budayasa, I. K., \& Juniati, D. (2017). The analysis of mathematics teachers' learning on algebra function limit material based on teaching experience difference. AIP Conference Proceedings. https://doi.org/10.1063/1.4994459

Nazir, M. (2009). Metode Penelitian. Bogor : Ghalia Indonesia.

Ngilawajan, D. A. (2013). Proses Berpikir Siswa SMA dalam Memecahkan Masalah Matematika Materi Turunan Ditinjau Dari Gaya Kognitif Field Independent dan Field Dependent. PEDAGOGIA: Jurnal Pendidikan, 2(1), 71-83. https://doi.org/10.21070/pedagogia.v2i1.48

Noor, J. (2016). Metodologi Penelitian: Skripsi, Tesis, Disertasi \& Karya Ilmiah. Jakarta :Prenada Media.

Pane, A., \& Darwis Dasopang, M. (2017). Belajar dan Pembelajaran. FITRAH:Jurnal Kajian Ilmu-Ilmu Keislaman, 3(2), 333-352. https://doi.org/10.24952/fitrah.v3i2.945

Pask, G. (1976). Styles and Strategies of Learning. British Journal of Educational Psychology, 46(2), 128-148. https://doi.org/10.1111/j.2044-8279.1976.tb02305.x

Pask, G., \& Scott, B. C. E. (1973). Caste: A system for exhibiting learning strategies and regulating uncertainties. International Journal of Man-Machine Studies, 5(1), 17-52. https://doi.org/10.1016/S0020-7373(73)80008-2

Posamentier, A. S., \& Krulik, S. (2015). Problem-solving Strategies In Mathematics: From Common Approaches To Exemplary Strategies. Singapore: World Scientific Publishing Company.

Rahman, A., \& Ahmar, A. S. (2016). Exploration of mathematics problem solving process based on the thinking level of students in junior high school. International Journal of Environmental and Science Education, 11(14), 7278-7285. https://doi.org/10.5281/zenodo.240664

Rehalat, A. (2016). Model Pembelajaran Pemrosesan Informasi. Jurnal Pendidikan Ilmu Sosial, 23(2), 111. https://doi.org/10.17509/jpis.v23i2.1625

Saul, M. (2008). Algebra: The mathematics and the pedagogy. In C.E. Greenes \& R. Rubenstein (Eds), Algebra and algebraic thinking in school mathematic. Reston, VA: The National Council of Theachers Mathematics, Inc.

Siswono, T. Y. E. (2016). Proses Berpikir Kreatif Siswa dalam Memecahkan dan Mengajukan Masalah Matematika. Jurnal Ilmu Pendidikan, 15(1), 60-68.

Sugiyono. (2018). Metode Penelitian Kombinasi (mixed Methods). In Bandung :Alfabet.

Supriadi, D., Mardiyana., \& Subanti, S. (2015). Analisis Proses Berpikir Siswa Dalam Memecahkan Masalah Matematika Berdasarkan Langkah Polya Ditinjau Dari Kecerdasan Emosional Siswa Kelas Viii Smp Al Azhar Syifa Budi Tahun Pelajaran 2013/2014. Jurnal Elektronik Pembelajaran Matematika, 3(2), 204-214.

Suyono, H. (2011). Belajar dan pembelajaran Teori dan konsep Dasar. Bandung: PT Remaja Rosdakarya. Ulya, H., Kartono, \& Retnoningsih, A. (2014). Analysis of Mathematics Problem Solving Ability of Junior High School Students Viewed From Students' Cognitive Style. International Conference on Mathematics, Science, and Education 2014 (ICMSE 2014) M.

Xiong, A., \& Proctor, R. W. (2018). Information Processing: The Language and Analytical Tools for Cognitive Psychology in the Information Age. Frontiers in Psychology, 9(1), 1-17. https://doi.org/10.3389/fpsyg.2018.01270 